\title{
Abiotic factors, not herbivorous pressure, are primarily responsible for the performance of an invasive aquatic plant
}

\author{
Márcio José Silveira ${ }^{1,2, *}$, Simon Chollet ${ }^{2}$, Gabrielle Thiébaut ${ }^{2}$ and Sidinei Magela Thomaz ${ }^{1}$ \\ ${ }^{1}$ Universidade Estadualde Maringá - UEM Research Group Ichthyology Aquaculture - Nupelia, Av Colombo 5790 Cep 87020-900, \\ Maringá, Paraná, Brazil \\ ${ }^{2}$ Laboratoire Ecosystemes, Biodiversité, Evolution (ECOBIO), UMR 6553 CNRS, University of Rennes 1, 35042 Rennes, France
}

Received: 8 August 2017; Accepted: 17 January 2018

\begin{abstract}
Morphological performance of invasive plants can be determined by abiotic factors (e.g. water temperature) and biotic factors (e.g. herbivory). This study investigates the performance of an exotic plant in its native and introduced environments. The questions of study are: Is the performance of Egeria densa in both its native and introduced areas associated with abiotic and/or biotic factors? Is the performance of this plant better in the native or in the introduced area? In order to answer these questions, E. densa individuals collected in France (introduced range) were compared with individuals collected in Brazil (native range). The results demonstrate that $E$. densa populations sampled in its native areas included a higher percentage of plants grazed than in the introduced range populations, but they also exhibited a superior performance in terms of length and dry mass. In both regions, the performance of the plants was associated mainly with abiotic factors. Whereas the higher temperature in its native area may have promoted greater growth in terms of length and dry mass, a lower temperature and high levels of ammonium in French waters might have reduced the development of this plant in its introduced range. The lower performance of $E$. densa in France should not be associated with abiotic factors alone, since other factors can also be involved, as limited resources or low clonal adaptation. Thus, future studies concerning $E$. densa performance in France should consider these factors in order to assist in understanding the nature of the plant's invasiveness in this region.
\end{abstract}

Keywords: Egeria densa / Brazil / France / growth / herbivory

\section{Introduction}

Non-native invasive plants are significantly problematic in many freshwater systems worldwide (Dugdale et al., 2012; Riis et al., 2012). These plants have a severe impact on the biodiversity, and the ecological functions of aquatic ecosystems (Clayton and Edwards, 2006), and will probably invade new areas owing to global changes (Carey et al., 2016; MacIsaac et al., 2016). Thus, these organisms are appropriate for testing ecological theories related to species invasion; for example, the 'Enemy Release Hypothesis' (ERH) (Keane and Crawley, 2002).

A fundamental mechanism determining the success of invasive plants in novel environments is the interaction between plants and herbivores. The herbivory in freshwater and marine ecosystems remove $40 \%-48 \%$ of plant biomass, on average, which is typically 5-10 times greater than that reported for terrestrial ecosystems (Bakker et al., 2016). Some studies have demonstrated that non-native plant species are less grazed in

\footnotetext{
*Corresponding author: s.marciojs@gmail.com
}

their introduced ranges than in their region of origin (Xiong et al., 2008), because there are fewer herbivores in their introduced range (Wolfe, 2002; Mitchell and Power, 2003). During their adaptation to a new habitat, non-native plants evolve sophisticated mechanisms to establish a balance between growth and defense (Walling, 2009). For example, plants might reduce in response to the effects of herbivores if their relative growth rate is high enough to sustain the grazing losses in an annual yield (Grime et al., 1996). Small, thin, nutrient-rich leaves with a high water content, are features typical of many submerged aquatic plants, which are readily grazed (Sheldon, 1987; Fraser and Grime, 1999). This demonstrates that despite the high growth rate of some plants, they are readily consumed by herbivores due to their nutritional qualities.

The ERH suggests that non-native species often thrive, because in their new ranges they lack the coevolved enemies that limit their population growth (Keane and Crawley, 2002; Mitchell and Power, 2003). However, several examples exist in which plants and their enemies have both been introduced into the same region. For example, the insect Megastigmus atedius Walker was introduced concurrently with its host plant, Picea sp., in western France (da Ros et al., 1993). In such cases, the 
species may be similarly impacted by herbivores in the introduced, and the native ranges. Some experimental studies have compared the damage due to herbivory on plant species in their introduced range (Agrawal and Kotanen, 2005; Chun et al., 2010), but not in both the introduced and the native regions.

Although the presence of herbivores may induce morphological modifications, such as an increase in leaf thickness, the architecture of macrophytes also depends on abiotic factors. Bornette and Puijalon (2011) demonstrated that abiotic factors in aquatic habitats can affect (1) plant performance, such as recruitment, growth, reproduction, and dispersal; and (2) the dynamics of plant communities. Temperature and nutrients are important abiotic factors influencing the growth of macrophytes and their productivity (Santamaria and Van Vierssen, 1997; Netten et al., 2010). For example, the seasonal growth patterns of Elodea canadensis Michaux, and the growth and rates of photosynthesis of Ranunculus aquatilis L. are strongly influenced by temperature (Madsen and Brix, 1997).

In this study, the morphological performance of Egeria densa Planch (Hydrocharitaceae) (E. densa) was explored in situ, in relation to the chemical composition of the water, and to the pressure by herbivores in its native range of Brazil, and its introduced range of France. E. densa is a perennial dioecious aquatic plant, native to South America's Neotropical range (Yarrow et al., 2009). This species has become invasive in several countries, such as Australia, New Zealand, Asia, and Europe (Gassmann et al., 2006; Yarrow et al., 2009). It was introduced in France in 1920 as an experimental botanical material (St John, 1961), and was consequently released into the wild, where it has subsequently become naturalized, and its distribution has spread (Feuillade, 1961). Moreover, it is invasive in the western part of France, in Brittany, and along the Atlantic Coast (Thiébaut et al., 2016).

Therefore, the questions for this study were: (i) Is the performance of $E$. densa, inferred by plant length, number of shoots, leaf area, and plant biomass, in both its native and introduced areas associated with abiotic factors, such as water characteristics, or with biotic factors, such as herbivorous pressure? Moreover, (ii) is this performance better in its native, or in its introduced area? In order to answer these questions, plants collected in France (introduced range) were compared with plants collected in Brazil (native range), at the beginning of the growing season in both regions.

\section{Methodology}

Plants and water samples were collected in spring from freshwater ecosystems in Brazil and in France. The first samples were collected in November 2012, from 19 georeferenced sites in south-eastern Brazil (Table S1). In April and May 2013, apical shoots of E. densa were collected from 12 georeferenced sites in the Brittany region of western France (Table S1). In both countries, E. densa forms monospecific, or pauci-specific, dense mats. Its natural habitat is the streams and lakes of the Paraná-Uruguay basin, and the Pampean plains (Walsh et al., 2013), and the streams and rivers of the coastal plain (Camargo et al., 2006). In its native area, $E$. densa is consumed by its specific herbivore, the leafminer fly (Hydrellia sp.) (Cabrera Walsh et al., 2013). In France, and specifically in Brittany, the main herbivores found in freshwater are Potamopyrgus antipodarum Smith (alien), Pysella acuta Draparnaud (alien), Ephemerella ignita Poda (native), Oecismus monedula Hagen (native), Nemotaulius punctatolineatus Retzius (native), Halesus radiates Curtis (native), and Mystacides azurea L. (native) (Piscart, personal communication). The natural enemies of $E$. densa in its introduced range remain unknown, although the species may be consumed by the generalist herbivore, Lymnea stagnalis L. (native), as evidenced in an experimental garden in Brittany (Thiebaut, unpublished data). In both countries, the plants were sampled in the littoral zone of the aquatic environment using a rake with a 4-metre long pipe; the sites were characterized by high under-water light levels. The exploration extended to four metres in depth, to the level colonized by the submersed aquatic plants. At each site, 20 individual mature plants were collected from the specimens forming a canopy on the water surface (native range 19 sites $=380$ individuals, and introduced range 12 sites $=240$ individuals). The plants were packaged in plastic bags, and taken to the laboratory to measure their morphological traits.

In order to characterize the environmental conditions in which the E. densa was growing, the water characteristics of each site were assessed by measuring the water temperature and conductivity in the field. In addition, nitrate, ammonium, and phosphate samples were taken to the laboratory within $48 \mathrm{~h}$ following collection, where the levels of these nutrients in the water were measured.

The performance of each population was tested using a 'traits approach' (Thiébaut and Di Nino, 2009). In the laboratory, the plants were washed to remove invertebrates, algae, and debris. The following traits were then measured: (1) plant length; (2) number of lateral shoots; (3) area of a leaf located at the sixth whorl; (4) number of roots; (5) plant dry mass (fragment + lateral shoots + roots); (6) percentage of plants grazed; (7) dry matter content (DMC); and (8) plant nitrogen $(\mathrm{g} \cdot \mathrm{DW})$. The traits (1) to (5) relate to the plant's performance, whereas the traits $6-8$ are indicators of plant palatability. Generally, there is a positive relationship between the nitrogen content of the plant's tissue and its consumption by herbivores (Cebrian and Lartigue, 2004). Submerged plants, such as $E$. densa, require fewer structural components compared to terrestrial plants, resulting in a higher nitrogen content, and consequently attract higher rates of herbivory (Bakker et al., 2016).

In order to estimate the percentage of plants grazed per site, the presence or absence of herbivory signals in each individual sample were quantified, and then, to calculate the percentage of consumed plants $(Z)$ per site, the following equation was used:

$$
Z=(X / N) * 100
$$

where $X$ is the number of plants damaged by herbivores, and $N$ is the number of plants sampled per site.

The DMC and total nitrogen content are known to influence consumption rates in plant's. The DMC is a plant trait that reflects plant palatability, with higher values of DMC indicating a low palatability (Elger and Willby, 2003). In order to assess the DMC, fresh plant apices were weighed, dried $\left(72 \mathrm{~h}\right.$ at $\left.60^{\circ} \mathrm{C}\right)$, and then re-weighed. The percentage of DMC $(\%)$ was calculated as the ratio between the fresh mass $(F M)$, 
and the dry mass $(D M)$, of the apices $(n=35$ for the native range, and $n=30$ for the introduced range), using the equation:

$$
D M C=(D M / F M) * 100
$$

In order to measure nitrogen content of the plant tissues, the macrophytes were ground to a powder and analyzed for total nitrogen with a CE Thermoquest Elemental Analyser model NA 2100 (Carlo Erba Instruments), using gas-liquid chromatography with EDTA as a standard. For the samples collected at Brazil, the Kjeldahl method was employed (Bremner, 1965).

\subsection{Statistical analyses}

Nonmetric multidimensional scaling was employed to visualize the differences between the native and the introduced areas of the E. densa population, in terms of its characteristics and life history traits. This analysis was implemented using a Bray-Curtis dissimilarity distance matrix, with the package 'vegan' (Oksanen et al., 2016) in the R 3.2.3 environment (R Core Team, 2016). The differences between the countries were evaluated using an analysis of a similarity test, employing a 999 permutation (ANOSIM, Oksanen et al., 2016). This analysis was conducted on morphological traits, abiotic variables, and herbivory percentage.

In order to test the possible differences among the morphological traits related to the plants' performance, such as plant length, number of shoots, leaf area, plant dry mass, and number of roots, between the native and introduced ranges, the Kruskal-Wallis ANOVA was employed. The analysis was conducted at a $p<0.05$ level of significance.

Spearman's Correlation Coefficients were calculated to measure the relationship between the percentage of plants grazed $\times$ foliar nitrogen percentage, and the percentage of plants grazed $\times$ DMC. Afterwards, in order to test the associations between the continuous variables in terms of the abiotic variables, and the percentage of plants grazed, and the response variables such as plant length, number of shoots, area leaf, plant dry mass, and number of roots, the average values for each site were utilized, and a backward conditional linear regression analysis was employed, in which all potentially relevant variables were included in the first step. Only the variables presenting $P$ values lower than 0.05 persisted in the next step. In the case of significant collinearity between two variables, only the more relevant persisted in the subsequent step. The decision concerning which variables should be excluded from the analysis at each step was made by the software. P values lower than 0.05 were considered significant. All of the data was analysed using STATISTICA software, Version 10 (StatSoft Inc., 2007).

\section{Results}

The results demonstrated that, with the exception of $\mathrm{PO}_{4}^{-}$ and $\mathrm{pH}$, there was a significant difference between Brazil and France for all variables (Table 1). Moreover, the French habitats showed greater values of $\mathrm{NO}_{3}^{-}, \mathrm{NH}_{4}^{+}$and conductivity, while the Brazilian habitats possessed greater values in terms of temperature and leaf nitrogen.
Table 1. Comparison of the water abiotic variables and leaf nitrogen level between Brazil and France (average and standard deviation and $p$ values).

\begin{tabular}{lccrr}
\hline Response variables & Brazil & France & \multicolumn{1}{c}{$Z$} & \multicolumn{1}{c}{$p$} \\
\hline $\mathrm{NO}_{3}^{-}$ & $0.14 \pm 0.04$ & $1.71 \pm 0.70$ & $-4.62<0.001$ \\
$\mathrm{NH}_{4}^{+}$ & $0.01 \pm 0.003$ & $1.35 \pm 0.35$ & $-4.62<0.001$ \\
$\mathrm{PO}_{4}^{+}$ & $0.007 \pm 0.002$ & $0.01 \pm 0.01$ & 0.52 & 0.590 \\
Conductivity & $63.31 \pm 4.08$ & $367.27 \pm 106.47$ & $-4.32<0.001$ \\
$\mathrm{pH}$ & $7.71 \pm 0.74$ & $7.82 \pm 0.74$ & -0.85 & 0.394 \\
Temperature & $27.45 \pm 1.69$ & $14.09 \pm 0.71$ & $4.62<0.001$ \\
Leaf nitrogen & $3.28 \pm 0.21$ & $2.55 \pm 0.30$ & $3.85<0.001$ \\
\hline
\end{tabular}

The nonmetric multidimensional scaling (Fig. 1) demonstrated that the Brazilian and French populations differ, and this was confirmed by the analysis of similarity $(R=0.89$, $\mathrm{p}$-value $=0.001)$. Furthermore, the Brazilian populations of $E$. densa were characterized by a higher dry mass, and the fact that they grow in warmer waters, while the French populations grow in water with a high concentration of $\mathrm{NH}_{4}^{+}$and $\mathrm{NO}_{3}^{-}$, and a higher conductivity (Fig. 1).

The correlation between the percentage of plants grazed and the nitrogen in plants was significantly positive $(R=0.32$; $p=0.009)$, indicating that the herbivory levels increased with the levels of plant nitrogen. In contrast, the correlation between the percentage of plants grazed and the DMC was not significant $(R=-0.051 ; p=0.698)$.

Significant differences existed between all of the morphological traits in the native, and the introduced ranges. The native populations of $E$. densa showed a significantly higher plant length $(Z=11.09 ; p<0.001)$, number of lateral shoots $(Z=4.73 ; p<0.001)$, leaf area $(Z=10.83 ; p<0.001)$, and plant dry mass $(Z=15.01 ; p<0.001)$ than the introduced populations (Fig. $2 \mathrm{a}-2 \mathrm{~d}$ ). In contrast, the number of roots was significantly greater in the plants sampled in the introduced population, as opposed to the native populations $(Z=-9.23$; $p<0.001$; Fig. 2e). The native populations also showed a significantly greater percentage of plants grazed than the introduced populations $(Z=2.34 ; p<0.019$; Fig. 2f).

The Table 2 shows the results of backward stepwise regression, which demonstrated that different abiotic variables were selected for each morphological trait. For example, the plant length and leaf area were negatively related with $\mathrm{NO}_{3}^{-}$ and $\mathrm{NH}_{4}^{+}$, respectively, while the number of roots and plant dry mass were positively related with conductivity and temperature.

\section{Discussion}

The results of this study indicate that the plant architecture in terms of the biomass and number of shoots, and the percentage of plants grazed differed between the native and the introduced populations. The $E$. densa populations were more grazed in Brazilian, compared with French freshwaters. Moreover, the morphological traits measured in terms of plant length, number of lateral shoots, leaf area, and plant dry mass, were significantly higher in its native range than its introduced range, with the exception of the number of roots. 
M.J. Silveira et al:: Ann. Limnol. - Int. J. Lim. 2018, 54, 12

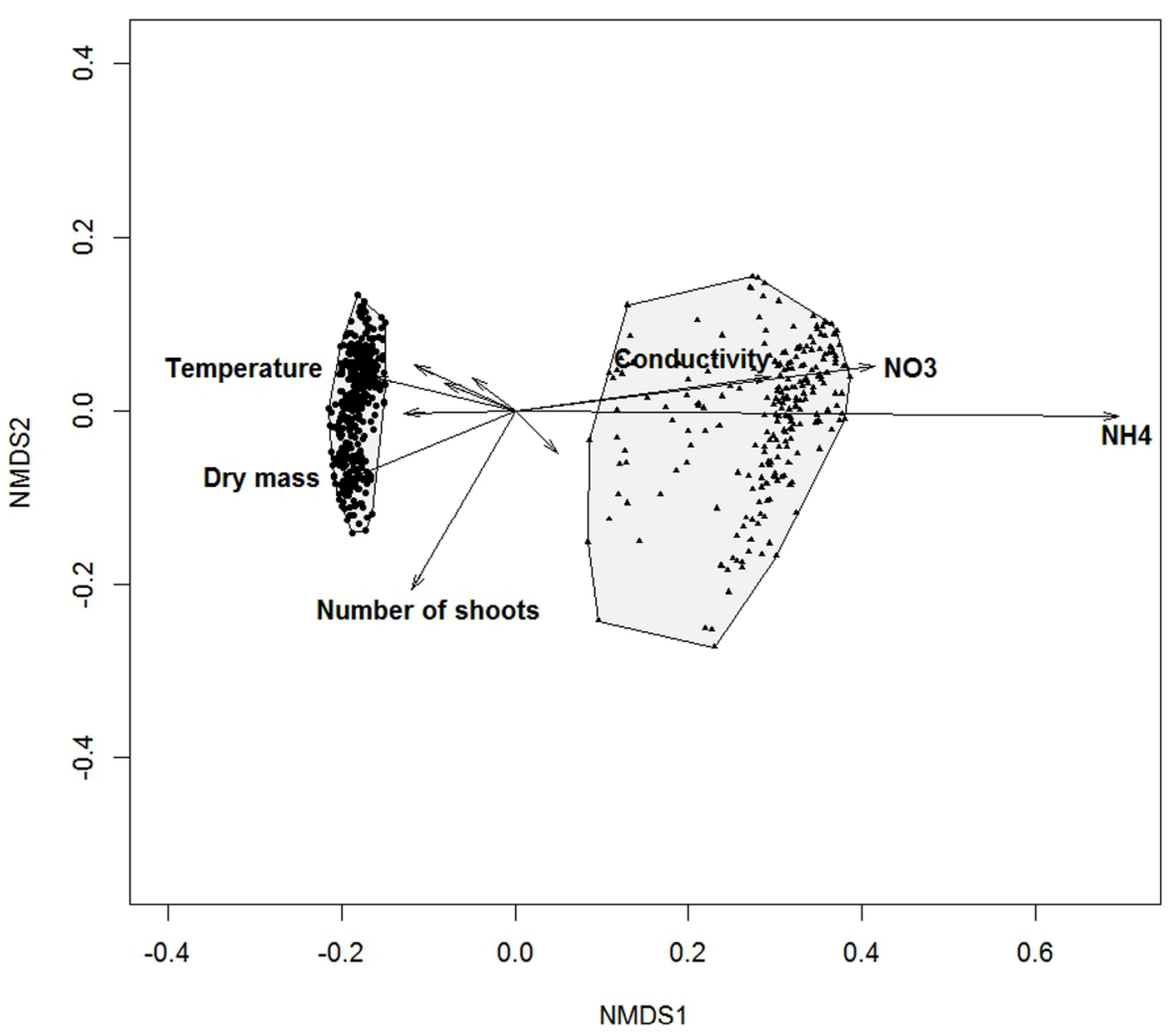

Fig. 1. Nonmetric multidimensional scaling (NMDS). The right-hand group of points represent the French plants, while the left-hand group represent the Brazilian plant's.

Some authors have demonstrated that the relationship between growth and percentage of plants grazed depends significantly on the level of specialist herbivores, or the pathogen loads that invasive species encounter in a new range (Willis et al., 1999). For example, the leafminer fly Hydrellia sp., which can cause heavy defoliation of $E$. densa in the field, is specific to $E$. densa in its native range (Walsh et al., 2013), but was not recorded at the sampled sites in the introduced range of France. In its native range, E. densa probably tolerates a higher degree of leaf damage, and possesses a greater performance due to its compensatory growth (Strauss and Agrawal, 1999). Fast growing species, such as E. densa, allocate less energy for defense against enemies than for growth (Blumenthal et al., 2009); however, this strategy differed between the native and introduced populations. The native population demonstrated low resistance, and was consequently more grazed, but showed a high development of all morphological traits, with exception of the number of roots, whereas in the introduced range, the population possessed a lower development, but a high herbivore resistance.

The regrowth capacity in terms of tolerance to herbivory, and the vigor of $E$. densa during the growing season in its native range, as indicated by a higher number of lateral shoots, dry mass, stem length, and specific leaf area, were likely associated with higher nutritional quality in terms of high nitrogen levels. Furthermore, the results demonstrated a greater percentage of leaf nitrogen in the population sampled in the native, as opposed to the introduced range, suggesting that greater herbivory tolerance was a strategy employed by $E$. densa in its native range in the form of 'tolerance-escape syndrome' (Agrawal and Fishbein, 2006), whereas the low nutrient content of $E$. densa in the introduced area indicated a 'low nutritional quality syndrome' (ibid.).

Aquatic plants are potentially exposed to herbivorous invertebrates throughout most of the year, with the predation by these organisms particularly high during the onset phase of plant growth, because detrital or periphytic food sources are scarcest during this period of initial growth (Elger and Willby, 2003). Moreover, the metabolic rate of grazers is accelerated by rising water temperatures, a factor that can assist in explaining the high percentage of plants grazed found in the plants sampled in Brazil, where the waters are warmer.

Some studies have indicated that the level of damage by herbivores in aquatic plants is also related to their nutritional quality (Newman et al., 1996; Bakker et al., 2016), and that the herbivory level is higher when there is an increase in the concentration of nitrogen in the macrophyte tissues (Kornijow et al., 1995; Martínez et al., 2013). The findings of this study concurred, since there was a positive correlation between the percentage of plants grazed and the nitrogen in the plant tissues. Moreover, the higher nitrogen content in the plants in the native range also assists in explaining the high percentage of plants grazed in this region.

The DMC is another plant trait that reflects its palatability (Elger and Willby, 2003). In general, the higher values of this trait indicate low plant palatability. In this study, there was not a significant correlation between the percentage of plants grazed and the DMC, therefore other traits might be involved in the plant's defense against herbivores. For example, the 

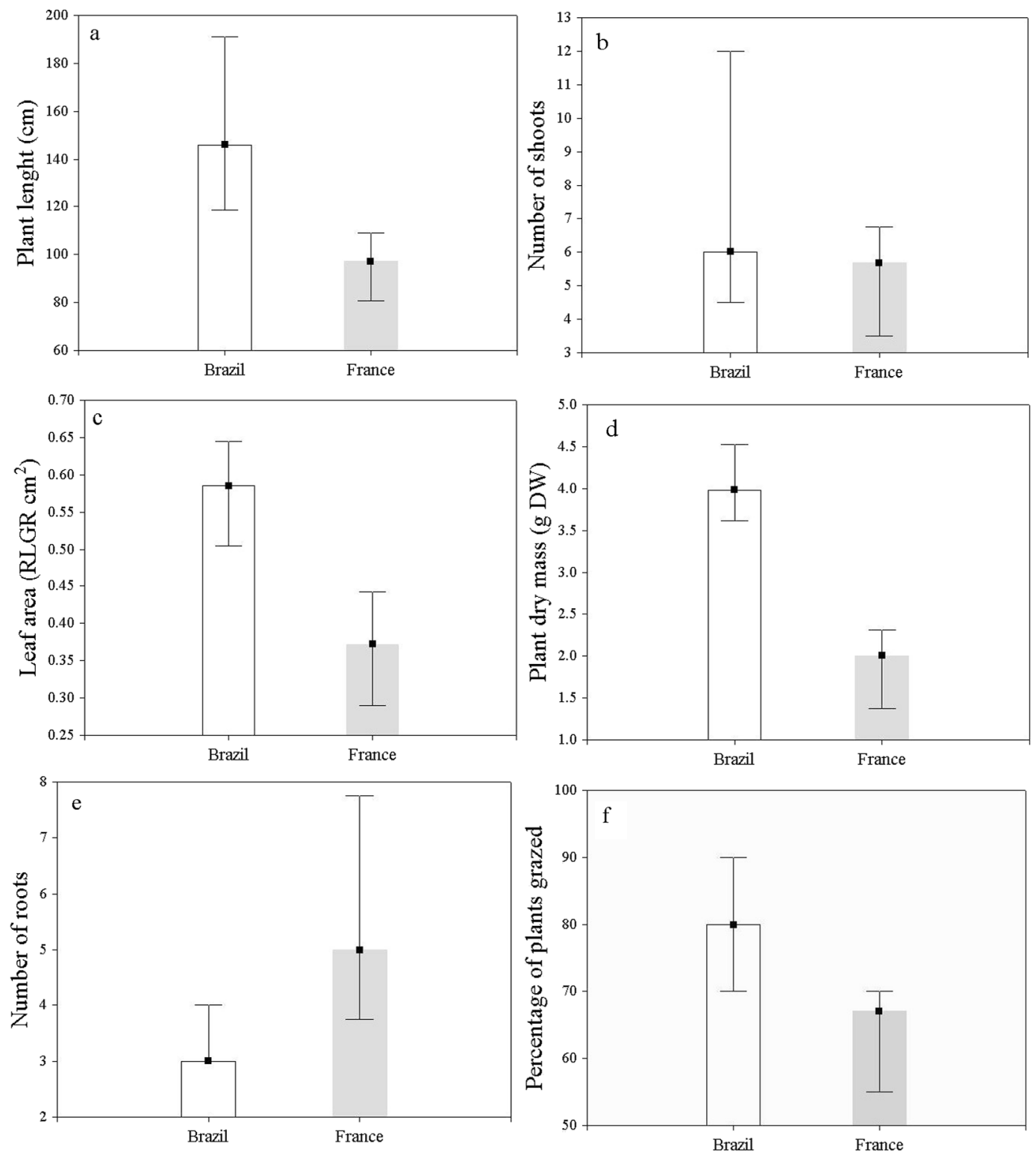

Fig. 2. Differences in morphological traits and the percentage of plant's grazed (medians and interquartiles) between the populations of $E$. densa in the native (empty bars), and the introduced ranges (grey bars).

Table 2. Results of backward stepwise regression with the best variable selected by analysis for each morphological trait.

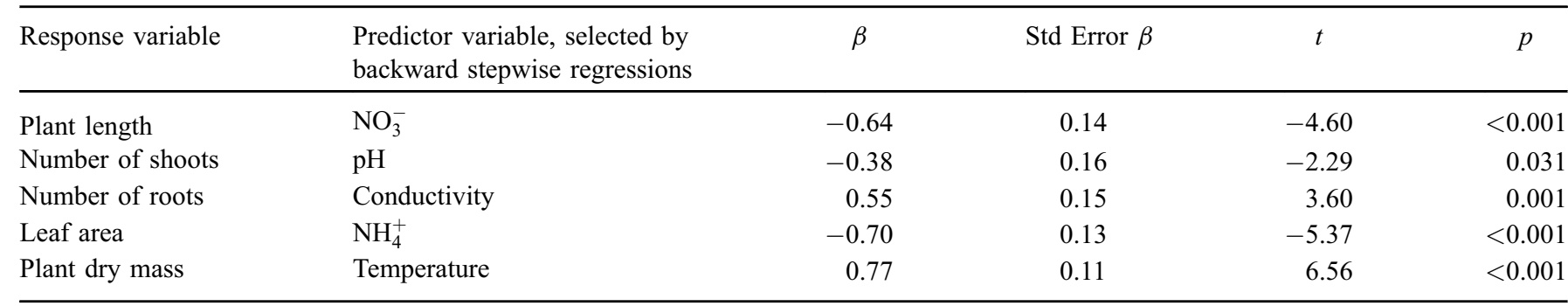

presence of herbivores can induce physical defenses such as leaf toughness, and chemical defenses such as phenolics, terpenoids, and nitrogenated compounds (Bakker et al., 2016). Although the interactions between plant's and their herbivores in freshwater have attracted much attention during recent decades, few studies have reported on the induced responses to herbivory in aquatic invasive plant's (Fornoff and Gross, 2014; Thiébaut et al., 2017). 
Regarding the performance of the plant in terms of plant length, number of shoots and roots, and plant dry mass, the results of this study demonstrated that the native populations exhibited a better performance than the introduced, corroborating other studies showing that not all invasive plant's has perform better in introduced ranges (Thébaud and Simberloff, 2001). The environmental features of the freshwater recorded in the introduced range may limit the growth of $E$. densa populations. For example, the presence of toxins and extreme temperatures constitute stressful conditions that may limit the metabolism, or the acquisition of resources (Thébaud and Simberloff, 2001), and consequently restrict the plant's growth. The results of this study demonstrated that the aquatic environments in which the plant's were sampled in the introduced area were characterized by greater ammonium levels in the water, compared with the sites where $E$. densa was sampled in its native range. Moreover, the stepwise regression demonstrated that the leaf area, primarily, was negatively related with the water ammonium levels (see, Table 2). Some authors have demonstrated that high ammonium concentrations in the water column can inhibit the growth of submerged macrophytes in eutrophic lakes (Smolders et al., 2003; Xie et al., 2007). Moreover, in eutrophic ponds, competition for space and resources may exist between benthic algae and $E$. densa, since the eutrophication stimulates the development of algae. For example, in some eutrophic French ponds, filamentous algae such as Cladophora sp. are found in conjunction with submerged aquatic plant's (unpublished data). In the native range, $E$. densa is found with other native and nonnative species of submerged macrophytes that may compete for space and/or resource use, such as Hydrilla verticillata - nonnative, Egeria najas Planch, Nitella sp., and Chara cf. guairensis (Ferreira et al., 2011; Thomaz et al., 2012). Although all traits related to the performance of the plant possessed lower values in the introduced than in the native range, the introduced populations of $E$. densa produced more roots. This higher root production could be considered a strategy to overcome stress, and to acquire nutrients efficiently in the French waterbodies, as shown by the positive correlation between the number of roots and nitrate. Some authors, such as Takayanagi et al., (2012) have demonstrated that nitrate can also be taken up by the roots of $E$. densa. Moreover, the root production could also be related to the characteristics of the sediment, for example the nutrient concentration, or grain size. Water temperature is another important factor that likely influenced the growth of the populations in both the native and the introduced ranges (Boros et al., 2011). In many cases, the colder temperatures in temperate countries explain why tropical and subtropical non-native species are not successful. A typical example is the rooted submerged macrophyte Myriophyllum aquaticum $\mathrm{L}$., which is common in many aquatic environments in the southern United States, and in western France, but is scarce in the colder regions of North America and France (Thiébaut, 2007). Most species of macrophytes die, or become dormant, at low temperatures (Lacoul and Freedman, 2006), however E. densa appears to possess a degree of tolerance to colder waters (Haramoto and Ikusima, 1988; Thiébaut et al., 2016), although a large decrease in the water temperature can inhibit the growth of this species, or even prove lethal (Leslie, 1992). The results of this study demonstrated a positive relationship between plant dry mass and temperature, indicating that the plant biomass increased with the increase in temperature. The French water was colder than the Brazilian, which may have contributed to the lower biomass values of $E$. densa in the introduced area. In contrast, the higher temperatures found in its native range stimulated the increase in E. densa biomass.

In summary, despite the fact that this study measured a high percentage of plant's grazed in the sampled populations, it seems that herbivorous pressure was not primarily responsible for the performance of $E$. densa. The results showed that the populations of $E$. densa demonstrated a high percentage of plant's grazed in its native range, compared to the introduced range. Moreover, the plant demonstrated a greater performance in terms of plant length and dry mass in its native range than in its introduced range, and this performance was mainly associated with abiotic factors, such as higher water temperature. Evidence for this was consistent, since despite the Brazilian populations of $E$. densa possessing a higher percentage of plant's grazed, these populations demonstrated greater growth in relation to the French populations, suggesting that the higher temperature in the native area is able to compensate for the greater predation by herbivorous in this region, thereby supporting better growth in terms of the dry mass of $E$. densa. A similar situation was observed in the introduced range, where the lower development of $E$. densa was also associated with abiotic factors, as opposed to herbivorous predation. For example, it is likely that the high levels of ammonium, and the low water temperature, in French waters negatively affected the development of $E$. densa. Despite these findings, the lower plant performance in French freshwaters can be also associated with other factors, such as limited resources, or low clonal adaptation, in addition to the colder water temperature, and the higher ammonium levels in the water. Future studies regarding the effects of habitat characteristics, and the influence of genetic variability are required in order to achieve a better understanding the success of $E$. densa in France.

Acknowledgements. We would like to thank Thaísa Sala Michelan, Bertrand Coupé, and Marc Hervé for their help in the field, and Nathalie Josselin-Le Bris for her assistance with the water analyses. S.M. Thomaz is especially thankful to the National Council for Scientific and Technological Development $(\mathrm{CNPq})$ for providing continuous funding through a Research Productivity Grant. M.J. Silveira thanks the Rennes Metropole, and CAPES, an organization of the Brazilian Government, for the training in human resources, and for providing a PhD scholarship.

\section{Supplementary Material}

Table S1. Coordinates of sites sampled in both regions, Native (Brazil) and introduced (France).

The Supplementary Material is available at https://www. limnology-journal.org/10.1051/limn/2018002/olm.

\section{References}

Agrawal A.A. Fishbein M., 2006. Plant defense syndromes. Ecology, 87, 132-149.

Agrawal A.A. Kotanen P.M., 2005. Herbivores and the success of exotic plant's: a phylogenetically controlled experiment. Ecol. Lett., 6, 712-715. 
Bakker E.S., Wood K.A., Pagés J.F., et al. 2016. Herbivory on freshwater and marine macrophytes: A review and perspective. Aquat. Bot., 135, 18-36.

Blumenthal D., Mitchell C.E., Pysek P., Jarosik V., 2009. Synergy between pathogen release and resource availability in plant invasion. PNAS, 106, 7899-7904.

Bornette G., Puijalon S., 2011. Response of aquatic plant's to abiotic factors: a review. Aquat. Sci., 73, 1-14.

Boros G., Sondergaard M., Takacs P., Vari A., Tatrai I., 2011. Influence of submerged macrophytes, temperature, and nutrient loading on the development of redox potential around the sediment-water interface in lakes. Hydrobiologia, 665, 117-127.

Bremner J.M. 1965. Total Nitrogen. In: C.A. Black (ed.), Methods of soil analysis. Part 2: Chemical and microbial properties. Number 9 in series Agronomy. American Society of Agronomy, Inc. Publisher, Madison, USA, 1049-1178.

Camargo A.F.M., Pezzato M.M., Henry-Silva G.G., Assumpcao A.M. 2006. Primary production of Utricularia foliosa L., Egeria densa Planchon and Cabomba furcata Schult \& Schult.f from rivers of the coastal plain of the State of Sao Paulo, Brazil. Hydrobiologia, 570, 35-39.

Carey M.P., Sethi S.A., Larsen S.J., Rich C.F., 2016. A primer on potential impacts, management priorities, and future directions for Elodea spp. in high latitude systems: learning from the Alaskan experience. Hydrobiologia, 777, 1-19.

Cebrian J., Lartigue J., 2004. Patterns of herbivory and decomposition in aquatic and terrestrial ecosystems. Ecol. Monogr., 74, 237-259.

Clayton J., Edwards T., 2006. Aquatic plant's as environmental indicators of ecological condition in New Zealand lakes. Hydrobiologia, 570, 147-151.

Chun Y.J., Kleunen M.V., Dawson W., 2010. The role of enemy release, tolerance and resistance in plant invasions: linking damage to performance. Ecol. Lett., 13, 937-946.

da Ros N., Ostermeyer R., Roques A., Raimbault P., 1993. Insect damage to cones of exotic conifer species introduced in arboreta. Interspecific variations within the genus Picea. J. App. Ento., 115, 113-133.

Dugdale T.M., Clements D., Hunt T.D., Butler K.L., 2012. Survival of a submerged aquatic weed (Egeria densa) during lake drawdown within mounds of stranded vegetation. Lake Reser. Manag., 28, 153-157.

Elger A., Willby N.J., 2003. Leaf dry matter content as an integrative expression of plant palatability: the case of freshwater macrophytes. Funct. Ecol., 17, 58-65.

Ferreira F.A., Mormul, R.P., Thomaz, S.M., Pott A., Pott V.J., 2011. Macrophytes in the upper Paraná river floodplain: checklist and comparison with other large South American wetlands. Revista de Biologia Tropical 59, 541-556.

Feuillade J., 1961. Une plante aquatique nouvelle pour la France Elodea densa (Planch.) Casp. Bull. Soc. Linn. Nor., 10, 47-51.

Fraser L.H., Grime J., 1999. Interacting effects of herbivory and fertility on a synthesized plant community. J. Ecol., 87, 514-525.

Fornoff F., Gross E.M., 2014. Induced defense mechanisms in an aquatic angiosperm to insect Herbivory. Oecologia, 175, 173-185.

Gassmann A., Cock M.J.W., Shaw R., Evans H.C., 2006. The potential for biological control of invasive alien aquatic weeds in Europe: a review. Hydrobiologia, 570, 217-222.

Grime J.P., Cornelissen J.H.C., Thompson K., Hodgson J.G., 1996. Evidence of a causal connection between anti-herbivore defence and the decomposition rate of leaves. Oikos, 77, 489-494.

Haramoto T., Ikusima I., 1988. Life cycle of Egeria densa Planch., na aquatic plant naturalized in Japan. Aquat. Bot., 30, 389-403.

Keane R.M., Crawley M.J., 2002. Exotic plant invasions and the enemy release hypothesis. Trends Ecol. Evol., 17, 164-170.
Kornijow R., Gulati R.D.T., Ozimek T., 1995. Food preference of freshwater invertebrates: comparing fresh and decomposed angiosperm and a filamentous alga. Fresh. Biol., 33, 205-212.

Lacoul P., Freedman B., 2006. Environmental influences on aquatic plant's in freshwater ecosystems. Environ. Rev., 14, 89-136.

Leslie A., 1992. Copper herbicide use-patterns in Florida waters. Florida Department of Natural Resources, Tallahassee, Florida, USA.

MacIsaac H.J., Eyraud A.P., Beric B., Ghabooli S.J. 2016. Can tropical macrophytes establish in the Laurentia Great Lakes? Hydrobiologia, 767, 165-174.

Madsen T.V., Brix H., 1997. Growth, photosynthesis and acclimation by two submerged macrophytes in relation to temperature. Oecologia, 110, 320-327.

Martínez S.F., Celeste F.M., Poi A., 2013. Food preference Neochetina eichhorniae (Coleoptera: Curculionidae) by aquatic plants of different nutritional value. Rev. Colom. Entomol., 39, 81-87.

Mitchell C.E., Power A.G., 2003. Release of invasive plants from fungal and viral pathogens. Nature, 421, 625-627.

Netten J.J.C., Arts G.H.P., Gylstar R., Vannes E.H., Scheffer M., Roijackers R.M.M., 2010. Effect of temperature and nutrients on the competition between free-floating Salvinia natans and submerged Elodea nuttallii in mesocosms. Fund. App. Limnol., 177, 125-132.

Newman R.M., Kerfoot W.C., Hanscom Z., 1996. Watercress allelochemical defends high-nitrogen foliage against consumption: effects on freshwater invertebrate herbivores. Ecology, 77, 23122323.

Oksanen J., Blanchet F.G., Kindt R., et al. 2016. Vegan: Community Ecology Package. R package version 2. 3-4.

R Core Team 2016. R: A language and environment for statistical computing. R Foundation for Statistical Computing, Vienna, Austria. URL https://www.R-project.org/.

Riis T., Olesen B., Clayton J.S., Lambertini C., Brix H., Sorrell B. 2012. Growth and morphology in relation to temperature and light availability during the establishment of three invasive aquatic plant species. Aquat. Bot., 102, 56-60.

Santamaria L., Van Vierssen W., 1997. Photosynthetic temperature responses of fresh- and brackish-water macrophytes: a review. Aquat. Bot., 58, 135-150.

Smolders S., McGrath S.P., Lombi E., et al. 2003. Comparison of toxicity of zinc on soil microbial processes between laboratory-contamined and polluted field Soils. Environ. Toxicol., 22, 2592-2598.

St John H., 1961. Monograph of the genus Egeria Planchon. Darwiniana, 12, 299-310.

Strauss S.Y., Agrawal A.A., 1999. The ecology and evolution of plant tolerance to herbivory. Trends Ecol. Evol., 14, 179-185.

Sheldon S.P., 1987. The effects of herbivorous snails on submerged macrophyte communities in Minnesota lakes. Ecology, 68, 1920 1931.

Takayanagi S., Takagi Y., Shimizu A., Hasegawa H., 2012. The shoot is important for high-affinity nitrate uptake in Egeria densa, a submerged vascular plant. J. Plant. Res., 125, 669-678.

Thébaud C., Simberloff D., 2001. Are plants really larger in their introduced ranges? Am. Nat., 157, 231-236.

Thiébaut G., 2007. Invasion success of non-indigenous aquatic and semi-aquatic plant's in their native and introduced ranges. A comparison between their invasiveness in North America and in France. Biol. Inv., 9, 1-12.

Thiébaut G., Di Nino F., 2009. Morphological variations of natural populations of an aquatic macrophyte Elodea nuttallii in their native and in their introduced ranges. Aquat. Inv. 4, 311-320.

Thiébaut G., Gillard M., Deleu C., 2016. Growth, regeneration and colonisation of Egeria densa fragments : the effect of autumn temperature increases. Aquat. Ecol., 50, 175-185. 
Thiébaut G., Boiché A., Lemoine D., Barrat-Segretain M.H., 2017. Trade-offs between growth versus defence in two phylogeneticallyclose invasive species. Aquat. Ecol., 50, 1-11.

Thomaz S.M., Agostinho A.A., Gomes L.C., et al. 2012. Using spacefor-time substitution and time sequence approaches in invasion ecology. Fresh Biol., 13, 2401-2410.

Yarrow M., Marin V.H., Finlayson M., Tironi A., Delgado L.E., Fischer F., 2009. The ecology of Egeria densa Planchon (Liliopsida: alismatales): a wetland ecosystem engineer? Rev. Chil. Hist. Nat., 82, 299-313.

Walling L.L., 2009. Adaptive defense responses to pathogens and insects. Plant. Innate. Immunity., 51, 551-612.

Walsh G.C., Dalto Y.M., Mattioli F.M., 2013. Biology and ecology of Brazilian elodea (Egeria densa) and its specific herbivore Hydrelia sp., in Argentina. Biol. Control., 58, 133-147.
Willis A., Thomas M., Lawton J., 1999. Is the increased vigour of invasive weeds explained by a trade-off between growth and herbivore resistance? Oecologia, 120, 632-640.

Wolfe L.M., 2002. Why alien invaders succeed: Support for the Escape-from-Enemy Hypothesis. Am. Nat., 160, 705-711.

Xie Y., Luo W., Ren Bo., 2007. Morphological and physiological responses to sediment type and light availability in roots of the submerged plant Myriophyllum spicatum. Ann. Bot., 100, 15171523.

Xiong W., Yu D., Wang Q., Liu C., Wang L., 2008. A snail prefers native over exotic freshwater plant's: implications for the enemy release hypotheses. Fresh. Biol., 53, 2256-2263.

Cite this article as: Silveira MJ, Chollet S, Thiébaut G, Thomaz SM. 2018. Abiotic factors, not herbivorous pressure, are primarily responsible for the performance of an invasive aquatic plant. Ann. Limnol. - Int. J. Lim. 54: 12 